\title{
Nuevo paradigma normativo sobre la ciudad: Retornando a la ciudad tradicional
}

\section{A new legal framework for the city: Returning to the traditional city}

$\underline{\text { J. Tejedor }}^{(*)}$

\section{RESUMEN}

El urbanismo español ha primado siempre el ensanche y la nueva edificación. La atención al tejido urbano y la edificación existentes ha sido marginal en la legislación y poco sistemática en la práctica. Tras la explosión de la burbuja inmobiliaria, pero no solo por esa razón, la realidad económica y financiera del país ha convertido en prioridad lo que era una necesidad, abordar con nuevos planteamientos el tratamiento de la ciudad y la edificación, promoviendo su regeneración integrada y energéticamente eficiente, impulsando un nuevo paradigma normativo mediante la Ley 8/2013, de 26 de junio, de rehabilitación, regeneración y renovación urbana.

Palabras clave: Deber de conservación; ruina; rehabilitación urbana; regeneración urbana.

\section{ABSTRACT}

Spanish urbanism has been characterized historically for giving priority to the urban sprawl and new buildings. The attention to the existing urban space and buildings has been marginal in the legislation and slightly systematic in the practice. After the explosion of the real-estate bubble, but not only for this reason, the economic and financial reality of Spain, has turned into a priority the treatment of cities and buildings with new approaches, promoting integrated and energetically efficient urban regeneration, stimulating a new normative paradigm with the Act 8/2013, of June 26, regarding urban renewal, regeneration and renovation.

Keywords: Duty of preservation; ruin; urban renewal; urban regeneration.

(*) Universidad de Zaragoza. Zaragoza (España).

Persona de contacto/Corresponding author: tejedorj@unizar.es (J. Tejedor)

Cómo citar este artículo/Citation: Tejedor, J. (2015). Nuevo paradigma normativo sobre la ciudad: Retornando a la ciudad tradicional. Informes de la Construcción, 67(EXTRA-1): mo22, doi: http://dx.doi.org/10.3989/ic.14.046.

Licencia/License: Salvo indicación contraria, todos los contenidos de la edición electrónica de Informes de la Construcción se distribuyen bajo una licencia de uso y distribución Creative Commons Reconocimiento no Comercial 3.o. España (cc-by-nc). 


\section{PLANTEAMIENTO. UN MODELO CENTENARIO QUE SIGUE AHÍ}

En un futuro no muy lejano el tiempo que hoy vivimos podrá señalarse como un punto de inflexión en la forma de abordar los problemas de ciudad y edificación y, más allá, en la configuración del sector y modelo inmobiliarios en España. Ley tras ley el modelo inmobiliario español ha superado guerras, regímenes políticos y episodios de corrupción. Impulsada la construcción desde principios del siglo xx como motor económico, cuantos gobiernos se han sucedido en España han asumido y potenciado ese modelo con normas, fondos públicos y una eficaz regulación del sector hipotecario como industria productora de crédito. Banca y cajas de ahorro producían el dinero y la deuda que alimentaban un proceso de expansión urbana y edificación que parecía imparable.

La clave fue la generación de crédito para financiar la expansión y la edificación y su repercusión al adquirente final del producto inmobiliario, configurándose así el promotor como mero gestor del riesgo inmobiliario, que asumía el coste y riesgo de comercialización, pero que se limitaba a captar crédito y a transferirlo a sus clientes obteniendo el beneficio más en la gestión del suelo que en el proceso de edificación. Urbanismo y edificación se convirtieron en instrumentos generadores de actividad económica que el Estado fomenta por su esencial importancia para el país. La economía se impuso así sobre el urbanismo. Prevalecieron los beneficios "para todos», desde los titulares originarios del suelo hasta los propietarios de vivienda usada y, por supuesto, las administraciones públicas, a través del sistema fiscal. El derecho urbanístico, anómalo, quedó al servicio de la economía (1).

No fue la presión de quiénes denunciaban los excesos, la depredación del territorio en muchas zonas del país, la corrupción y las «ruinas modernas» tan bien documentadas en la exposición del mismo nombre (2), que han surgido en numerosos municipios españoles, la que ha acabado con la expuesta forma de actuar. Fueron fundamentalmente, aunque no exclusivamente, parámetros económicos y financieros los que lo llevaron al colapso. Un conjunto de factores normativos, demográficos, organizativos, económicos, financieros y presupuestarios hicieron que nuestro país no haya tratado de abordar de manera integrada, sistemática, la problemática de la ciudad tradicional, hasta tiempos recientes. La ausencia de regulación adecuada resultaba clamorosa. La expansión proporcionaba plusvalías más rápidamente a los operadores inmobiliarios e ingresos fiscales a las Administraciones públicas. Hoy inviable, todo confluye hacia la ciudad tradicional, incorporando al país a líneas de trabajo ya presentes en otros países de nuestro entorno hace años, definiendo nuevos objetivos y diseñando técnicas operativas que tratan de facilitar su consecución superando las múltiples barreras existentes. Explicar este proceso y las líneas maestras de la nueva normativa son los objetivos fundamentales del presente trabajo.

En todo caso, conviene tener presente que el modelo normativo tradicional en España no ha caído, sigue indemne, listo para volver a ser aplicado, para auspiciar y amparar las mismas prácticas, basadas en la preservación de los privilegios legales del sector financiero, que le permiten continuar fabricando crédito y ejecutar expeditivamente las garantías prestadas por quienes no puedan hacer frente a los préstamos contraídos. El derecho urbanístico sigue también hoy, incólume. El ordenamiento jurídico de la expansión continúa vigente.

\section{APPROACH. A CENTENARIAN MODEL STILL VIABLE}

In a not so distant future, today will be referred as a turning point for urban and building problem solving and, what is more, for the reconfiguration of the housing sector and model in Spain. Law after law, the Spanish real-state model has overcome wars, political regimes and corruption episodes. Boosted by the construction industry since the $X X$ th century, and considered an economical engine, the successive governments have assumed and promoted this model with reforms, public investment and an efficient legal framework in the housing sector as a credit-producing industry. Savings and merchant banks used to produce money and debt that kept feeding an urban and building expansion that seemed unstoppable.

The key was the generation of credit in order to fund the urban and building expansion and its repercussion in the final buyer of the real-state product. The developer was thus configured as a mere market-risk manager, assuming the cost and the risk of commercialization, whose responsibility was limited to finding funds and transferring them to his clients, obtaining more benefit in the soil management than in the building process. Urbanism and construction became instruments, generators of economic activity promoted by the Administration due to their importance for the country. The economy was imposed over urbanism, prevailing the benefits "for everybody", from the original soil owners to the second hand dwellings owners, including of course the public administration through the tax system. The urban planning law, abnormally, remained at service of the economy (1).

It was not the pressure from those who denounced the excesses, the depredations of the territory in many areas of the country, the corruption and "modern ruins" so well documented in the exposition with the same name (2), which have flourished in many Spanish regions, the ones that have finished with the previously stated course of action. Economic and financial parameters were mainly, but not exclusively, the ones leading it to its collapse. An ensemble of regulatory, demographic, organizational, economic, financial and budgetary factors contributed to the fact that in our country the problem of the traditional city had not been addressed in a systematic and integrated way, until recently. The absence of a proper regulation was flagrant. The expansion guaranteed quick capital gains to the real estate operators and tax revenues to the Administration. Today this model results unfeasible, and everything converges on the traditional city, including the country in lines of work already present in other European countries for several years, requiring the definition of new objectives and the design of operative techniques that aim to facilitate their completion overcoming the multiple existing barriers. Explaining this process and the guidelines for this new legal framework are the main objectives of this article.

In any case, it is convenient to have in mind that the traditional legal framework in Spain has not yet fallen; it remains undamaged, ready to be used, to host and to maintain these very same practices, based on the preservation of the legal privileges of the financial sector, which allow to keep generating credit and expeditiously executing the issued guaranteed by those who cannot face the contracted loans. The urban planning law and the expansion legal system remain still intact. 


\section{LOS ORÍGENES. ENSANCHE CONTRA REFORMA INTERIOR}

Tras la Ley 8/2013, de 26 de junio, de rehabilitación, regeneración y renovación urbanas (L3R) contamos en España con dos cuerpos normativos atinentes a la ciudad. El primero, integrado por el texto refundido de la Ley de Suelo aprobado mediante el Real Decreto legislativo 2/2008, de 20 de junio (LS), el Reglamento de valoraciones aprobado por el Real Decreto 1492/2011, de 24 de octubre (RVS) y la normativa autonómica, regula el estatuto de la propiedad del suelo y las técnicas urbanísticas orientadas a la expansión urbana, con escasas e ineficaces previsiones sobre la ciudad existente. El segundo, el más reciente, basado en la L3R, incide sobre otras normas, incluida la LS, para lograr sus objetivos, incorporando un régimen específico muy completo para impulsar la rehabilitación, regeneración y renovación urbanas (3) (4) (5) (6).

La primacía en la normativa urbanística del ensanche se ha traducido en una clara preeminencia de la regulación de la nueva edificación sobre la rehabilitación. Así resulta claramente de la Ley 38/1999, de 5 de noviembre, de ordenación de la edificación (LOE), que ha venido contemplando la rehabilitación misma como cuestión incidental escasamente regulada. También la LOE se ha visto modificada por la L3R, al igual que el Código Técnico de Edificación, aprobado mediante Real Decreto 314/2006, de 17 de marzo (CTE). La marginalidad de la rehabilitación sobre el conjunto de actividad inmobiliaria en el país explica la escasa atención a la rehabilitación en la normativa técnica de edificación. La L3R ha reconducido en parte la situación eliminando el concepto de «obras de rehabilitación», derogando el art. 2.5 CTE, y adoptando el concepto de «intervención en los edificios existentes» [art. 2.2.b) LOE] y flexibilizando la regulación de la aplicación del CTE (art. 2.3, párrafos segundo y tercero, CTE) impidiendo la reducción de lo cumplido (art. 2.4, párrafo quinto, CTE). Se ha avanzado, sin duda, pero falta reflexión sobre las exigencias técnicas de la obra de intervención sobre edificios existentes.

Esta dualidad no es nueva. Ya en el último tercio del siglo XIX contábamos con dos regulaciones atinentes a la ciudad, sobre el crecimiento urbano, por un lado, y sobre la reforma interior, por otro. Desde la primera perspectiva, la del crecimiento, se sucedieron en ese periodo hasta tres leyes de ensanche $(1864,1876,1892)$ con sus respectivos reglamentos (7) (8) (9) (10) (11) (12). Las leyes de ensanche tenían por objeto la incorporación a la ciudad de los terrenos que constituían sus afueras con los equipamientos necesarios en una extensión proporcionada al aumento probable de la población. Dichas operaciones aparecían vinculadas al poder público, que ejercía sus facultades para hacerlas posibles, pero respetando escrupulosamente la propiedad privada al imponer al poder público las cargas financieras del ensanche aunque se beneficiasen del mismo fundamentalmente los propietarios. Como dijo Cerdá «cuando la Administración paga con fondos públicos... los terrenos y edificios en que haya de emplazarse una calle, compra a los propietarios a ella colindantes el derecho a hacerles más ricos, duplicando, cuando menos, el valor de los edificios y terrenos sitos a uno y otro lado de la nueva calle» (7). El plano del ensanche era aprobado por la administración pública y, en principio, se ejecutaba directamente por ésta, financiado por un presupuesto separado nutrido mediante fiscalidad especial y finalista sobre los propietarios. Pero la

\section{THE ORIGINS. ENSANCHE VERSUS THE INNER REFORM}

After the Act 8/2013, of 26 June, on urban renewal, regeneration and renovation (Ley de rehabilitación, regeneración y renovación urbanas, $L_{3} R$ ), in Spain there are two normative bodies referring to the city. The first one, integrated by the revised text of the Land Law (Ley del Suelo, LS) approved by the Royal Legislative Decree 2/20o8 of 2oth June, the Regulation of valuations (Reglamento de valoraciones, $R V S$ ) approved by the Royal Decree 1492/2011 of 24 October, and the municipal regulations, regulates the land ownership and the urban planning techniques, with scarce and inefficient considerations on the existing city. The second and most recent one, based in the L3R, affects also other laws, including the LS, in order to achieve their objectives, incorporating a specific and very complete regime to promote urban renewal, regeneration and renovation (3) (4) (5) (6).

The primacy in the urban planning of the ensanche has been translated into a clear pre-eminence of the regulations of new constructions regarding renovation, as can be inferred from the Law 38/1999, of 5 November, on Building Planning (Ley de Ordenación de Edificación, LOE), in which renovation matters are scarcely regulated. The $L O E$ has also been modified by the $L_{3} R$, as well as for the Technical Building Code (Código Técnico de la Edificación, CTE), approved by Royal Decree 314/2006 of 17 March. The marginality of the renovation with respect to the housing activity as a whole explains the scarce attention to renovation in the CTE. The $L_{3} R$ has redirected partly the situation, removing the concept of "refurbishment works", repealing article 2.5 of the CTE, and adopting the concept of "intervention in existing buildings" [art 2.2.b) LOE] and making more flexible the regulation of the CTE application (art. 2.3, second and third paragraphs, CTE) preventing the reduction of the requirements (art. 2.4, fifth paragraph, CTE). Undoubtedly, progress has been made, but there is still a lack of reflection on the technical demands of the intervention works in existing buildings.

This duality is not new. Already in the last third of the XIXth century, there were two regulations involving the city, one regarding its urban growth, and the other concerning the inner reform. From the first perspective -the one of the urban growth- three ensanche laws were developed (1864, 1876, 1892) with their respective regulations (7) (8) (9) (10) (11) (12). These laws aimed to incorporate to the city the lands constituting its outskirts with the necessary equipment, in an extension proportional to the foreseeable population growth. Such interventions were bonded to the Public Administration, which made them possible, but they scrupulously respected the private property since the Administration had the financial obligations of the ensanche besides the fact that the owners benefited from it. As Cerdá said, "when the Administration pays with public funding.... the lands and buildings, where a new street is to be set, are bought from the owners together with their right to become richer, increasing the value of the existing buildings and lands at both sides of the new street at least twice as much" (7). The plan of the ensanche was approved by the Public Administration and, in the beginning, was to be carried out directly by it, funded by a separated budget nurtured by a special tax treatment that aimed the owners. But the legislation of the ensanche envisioned and promoted in 
legislación de ensanche previó y potenció en sucesivas reformas bonificaciones fiscales a favor de los propietarios que cediesen y urbanizasen parte de las infraestructuras requeridas por el ensanche tratando de fomentar así su colaboración. Llegó a establecer la expropiación-sanción de aquellos propietarios que, siendo la colaboración mayoritaria, se negasen a asumir unas cesiones mínimas, en la Ley de 1876, o medias, en la de 1892. La semilla de la ejecución equidistributiva de la ejecución de los planes por los propietarios estaba sembrada.

Paralelamente se reguló la reforma interior, comprensiva de intervenciones desarrolladas en la ciudad consolidada (7) (10) (11). La Ley de Expropiación Forzosa de 1879 introdujo la expropiación para la reforma interior de las poblaciones que reuniesen "por lo menos 50.000 almas», previendo la expropiación por franjas laterales, posteriormente incorporada a la Ley sobre obras de mejora, saneamiento y reforma interior de las grandes poblaciones de 1895. Previó la Ley de 1879 que «estarán sujetas en su totalidad a enagenación (sic) forzosa para los efectos previstos en el artículo anterior, no solo las fincas que ocupen el terreno indispensable para la vía pública, sino también las que en todo o en parte estén emplazadas dentro de las dos zonas laterales y paralelas a dicha vía, no pudiendo sin embargo exceder de 20 metros el fondo o latitud de las mencionadas zonas» (art. 47), extensión que la Ley de 1895 amplió a 50 metros. Se estableció así un modelo de gestión urbanística apetecible para la iniciativa privada, dado que «en las enajenaciones forzosas que exija la ejecución de la obra será regulador para el precio el valor de las fincas antes de recaer la aprobación al proyecto» (art. 49 Ley de 1879). Las plusvalías generadas por la ejecución del proyecto aprobado por el Gobierno, como las mejoras que hubiesen podido realizarse en la finca desde su iniciación (aunque esto lo matizase la Ley de 1895), no se tenían en cuenta en las valoraciones. Configuradas como públicas, quedaban vinculadas a la gestión del proyecto. Eran posibles gestión directa e indirecta mediante concesión preferente desde 1895. Aun cuando la primera supusiese inicialmente mayores desembolsos para las arcas municipales, finalmente éstas podían verse recompensadas al ingresar toda la plusvalía derivada de las obras ejecutadas. Si la ejecución se realizaba mediante concesionario, en cambio, el Ayuntamiento solo ingresaba a través del canon concesional parte de las plusvalías, reteniendo el resto el concesionario. Ninguna preferencia tenían los propietarios.

La Ley sobre régimen del suelo y ordenación urbana de 12 de mayo de 1956 (LS1956) fue la cuarta Ley de ensanche (13), de nuevo poco preocupada por el suelo urbano ya urbanizado y ocupado por la edificación. Ciertamente, como puso de relieve la doctrina, la «rara calidad» de esta norma, que constituyó «una obra legislativa verdaderamente creadora y profunda» ha hecho que haya sido considerada por muchos «el verdadero acta de nacimiento de un Derecho urbanístico español por fin maduro, orgánico y omnicomprensivo, tan lejos del casuismo normativo, de las timideces y del arbitrismo ocasional de los cien años anteriores, animado de criterios técnicos profundos» (11). Pero la omisión de un adecuado tratamiento del suelo urbano, que no corrigió la reforma de 1975-1978, igualmente concebida para la expansión, generó muchos de los problemas actuales.

Entre tales técnicas y junto al establecimiento de un sistema de planeamiento y la configuración estatutaria del derecho de propiedad, estrechamente vinculados, el fundamental aporte successive reforms tax reductions in favor of those owners who granted and urbanized the infrastructures required by the ensanche, trying thus to promote their collaboration. The expropriation-sanction was later established in the case of majority collaboration for those owners who refused to assume a minimum of transfers, in the Act of 1876, and an average amount, in the one of 1891. The seed of the equidistributed implementation of the plans for the owners was sown.

Simultaneously, the inner reform was regulated; including interventions developed in the consolidated city (7) (10) (11). The Obligatory Expropriation Act (Ley de Expropiación Forzosa) of 1879 introduced the expropriation for the inner reform of the cities with "at least 50.000 souls", anticipating the expropriation by lateral stripes, subsequently added to the Act on land-improvement works, sanitation and the interior reform of large populations of 1895. The Act of 1879 anticipated that the following would be entirely subject to forced alienation for the purposes specified in the preceding article: not only buildings occupying the piece of land indispensable for public roads, but also in whole or in part those emplaced within the two side and parallel areas to such road, without exceeding 20 meters deep or latitude such areas (art. 47). The Act of 1895 extended this dimensions to 50 meters. It was established thus a model of urban management desirable for the private initiatives, providing that in forced disposals requiring the execution of the work the value of the buildings before the project approval would regulate the price (art. 49 Law of 1879). The capital gains generated by the approved implementation of the project by the Administration, as well as the improvements that could have been in the property since the process started (this is though specified in the Act of 1895) were not taking into consideration the valuations. Set as public, they were linked to the project management. Direct and indirect management was possible through preferential granting since 1895. Even if the former implied greater municipal investments, these were compensated later when receiving capital gains from the projects carried out. If the implementation was done through licensees, however, the City Council only received part of the capital through licensing canon, whereas the remaining was held by the concessionaire. The owners had no preference.

The Law regarding land and urban planning (Ley sobre régimen del suelo y ordenación urbana, LS1956) of 12 May 1956 was the fourth ensanche law (13), again not really addressing the urban soil already urbanized and covered with buildings. Certainly, as it was highlighted by the doctrine, the "rare quality" of this regulation, which constituted "a piece of legislation truly deep and creative", has been considered by many "a real birth certificate of a mature, organic and omni-comprehensive Spanish urban planning law, far from the legal casuistry, the shyness and the occasional arbitrariness of the last hundred years, full of deep technical criteria" (11). However, the omission of an adequate treatment of the urban soil, fact that was not corrected in the reform of 1975-1978 and also designed for expansion, generated many of the current problems.

Among such techniques and together with the establishment of a planning system and the statutory configuration of the property rights, closely linked between them, the fundamental contribution of the LS1956 was land 
de la LS1956 fue la reparcelación que, aunque contaba con antecedentes en normas anteriores, apareció en ella como el primer gran instrumento redistributivo de beneficios y cargas derivados del planeamiento entre los propietarios afectados. La reparcelación surgió muy vinculada a los intereses de la propiedad, a la que diversas normas impusieron como obligatoria la rectificación de límites precisa para la ejecución de las obras de urbanización exigidas por el planeamiento bajo sanción expropiatoria (11). No faltaron tampoco disposiciones que permitían a asociaciones de propietarios enclavados en el ámbito de un proyecto de urbanización parcial asumir voluntariamente los beneficios y cargas de su ejecución (11).

El modelo urbanístico español, inicialmente configurado como ámbito de obra pública que al beneficiar singularmente a determinados propietarios debía financiarse por éstos mediante la exacción de diversos tributos, evolucionó trasladando la carga de gestión a quienes quedaban obligados a asumir los costes atribuyéndoles además los beneficios. De la colaboración voluntaria de la propiedad se pasó a la imposición forzosa a la misma, bajo sanción expropiatoria con minusvaloración de la propiedad, de las obligaciones de urbanizar y edificar. En ese contexto, la autofinanciación de la actividad urbanística no solo hacía innecesaria cualquier aportación presupuestaria pública para la ejecución del planeamiento sino que generaba retornos en forma de cesiones y recaudación tributaria, como mínimo, a la Administración. Lo expresó perfectamente el legislador de 1956 en la exposición de motivos al criticar «la falta de distribución equitativa del aumento de valor del suelo, que debe ser afectado, en primer lugar, a amortizar los terrenos necesarios para vías y espacios libres; en segundo término, al pago de las obras de urbanización. Y, por último, atribuido justamente a los propietarios, de suerte que desaparezcan en lo posible las desigualdades actuales derivadas de conceder la edificación intensiva a unos mientras se niega o se limita excesivamente a otros». El presupuesto de todo ello es la equidistribución, plasmada en la reparcelación, una institución cuya fuerza expansiva pareció no tener fin mientras el urbanismo fue capaz de generar, sobre la base de un sistema crediticio concebido y dedicado a ello, cuantiosas plusvalías que para el país se tornaron en elevados niveles de deuda. Nada es gratis.

\section{EL TRIUNFO DE LA EQUIDISTRIBUCIÓN: DE LA AUTOFINANCIACIÓN DEL ENSANCHE AL URBANISMO FINANCIERO}

El derecho urbanístico español ha sido, en fase germinal desde la legislación de ensanche, y de madurez desde la LS1956, el derecho de la equidistribución, del reparto entre los propietarios de los beneficios potenciales de la actividad urbanística pública a cambio de la asunción de las cargas que la administración no podía asumir. En un contexto de administraciones públicas muy débiles financieramente la equidistribución era la puerta al Dorado. Nada debía aportar la administración para ejecutar sus decisiones de ordenación porque eran los propietarios los llamados prioritariamente a ejecutarlas.

La filosofía subyacente en la normativa decimonónica de reforma interior, conforme a la cual la totalidad de la plusvalía urbanística era pública y quedaba afectada al desarrollo de la actividad urbanística, cayó en el olvido admitiéndose como normal su posible apropiación privada e incorporándose legalmente su valor al del suelo, no mucho después, con la mera decisión de clasificación y sin necesidad de inversión alguna. subdividing. Even though there is record of this concept in previous laws, in the LS1965 land subdividing arose as the main redistributive instrument of benefits and burdens between the affected landlords. The land subdividing technique emerged strongly associated with the ownership interests, and several regulations made compulsory the rectification of the precise boundaries for the urbanization works, imposed by the regulation under expropriation sanction (11). There were also provisions that would enable owners associations, in the context of a partial urbanization project, to assume voluntarily the benefits and burdens of the implementation (11).

The Spanish urban planning model was initially configured as a field of public works that benefitted certain owners and had to be funded by them through tax enforcement. It evolved moving the management burden to those who were obliged to assume the cost, granting them the benefits as well. The voluntary owners association turned into the compulsory imposition of urbanizing and building obligations, under expropriation sanction and underestimation of the property. In that context, the self-funding of the urban activity made not only unnecessary any public funding for the projects implementation, but generated returns in the form of cessions and tax enforcement, at least, to the Administration. It was perfectly expressed by the legislator of 1956 when exposing his motivation to criticize "the lack of equitable distribution in the rise of the land value, which must be altered, should firstly be aimed to amortize the necessary lands for road and open spaces and, secondly, the urban development works payment. Finally, it should be fairly assigned to the owners, trying to eliminate as much as possible the inequalities derived from the intensive building concession to some whereas it is denied or limited to others". The budget for all of this is the equidistribution, embodied in the concept of land subdividing, an institution whose expansive strength seemed not to have an end as far as the urbanism was able to generate, based on a credit system conceived and dedicated to it, abundant capital gains that turned into a high level of debt for the country. Nothing is for free.

\section{THE SUCCESS OF THE EQUI-DISTRIBUTION: FROM THE SELF- FUNDING OF THE ENSANCHE TO FINANCING URBANISM}

The Spanish urban planning law has been, during its first stages of the ensanche legislation and during its maturity phase since the LS1956, the right of the equidistribution, of sharing among the owners the potential benefits of the urban activity in exchange of the acceptance of the burdens that the administration could not assume. In a context where public Administrations were too week financially, equidistribution was paradise. Nothing was to be provided by the Administration in order to implement the urban planning decisions because the owners were the ones who mainly had to execute them.

The underlying philosophy in the nineteenth-century framework of the inner reform, according to which all capital gains were public and were affected by the developments of urban activity, was forgotten and its private appropriation turned to be considered normal. Not much afterwards its economic worth was incorporated to the value of the soil by means of a mere classification and without the need of 
La renuncia fue explícita en la exposición de motivos de la LS1956 donde se admitió que «si ideal en la empresa urbanística pudiera ser que todo el suelo necesario para la expansión de las poblaciones fuera de propiedad pública, mediante justa adquisición para ofrecerle, una vez urbanizado, a quienes desearen edificar, la solución, sin embargo, no es viable en España. Requeriría fondos extraordinariamente cuantiosos, que no pueden ser desviados de otros objetivos nacionales, y causaría graves quebrantos a la propiedad y la iniciativa privadas». No es extraño que desde la reforma de 1975-1978 fuese la propia ley la que admitió el carácter privado de la plusvalía urbanística exigiendo, eso sí, la cesión de un porcentaje, concretado en una especie de diezmo urbanístico sobre el aprovechamiento medio del ámbito correspondiente, a la Administración. No había otro modelo posible que el equidistributivo.

La legislación urbanística primero y la ordenación urbanística después fueron incorporando instituciones y técnicas que trataban de laminar las tensiones que genera la asignación de usos al suelo, por un lado (14), y de lograr un equitativo reparto de beneficios y cargas entre los propietarios por otro (11). De todo ello emergieron, junto a la reparcelación, el aprovechamiento medio, el aprovechamiento tipo, las transferencias de aprovechamientos, las reparcelaciones económicas forzosas en suelo urbano, las compensaciones entre ámbitos excedentarios y deficitarios y otras instituciones análogas. Esa filosofía reparcelatoria, esa anticipación de la gestión, condicionó las determinaciones de planeamiento y se encuentra en la base del derecho urbanístico actual. De ese ordenamiento urbanístico, que busca promover la actividad económica, que revalúa el suelo con la mera aprobación del planeamiento, que encomienda la gestión y asigna la mayor parte de las plusvalías a los propietarios del suelo porque el «ideal de la empresa urbanística» resultaba inalcanzable, surgieron nuestras ciudades y pueblos en su concreta conformación actual.

Las técnicas de reparto equitativo de beneficios y cargas nacieron, así, de la necesidad de encontrar quien financiase la ejecución de unos planes que, por su contenido, generaban desigualdad entre los propietarios afectados. Se trataba de corregir lo que la doctrina llamó la lotería del planeamiento (10) (13), el premio que los titulares de las fincas con aprovechamientos lucrativos recibían con la mera aprobación del plan. Para corregirla la LS1956, en un contexto legislativo favorable a los propietarios, reguló la reparcelación reformulando el concepto de propiedad privada y función social. La reforma de 1975-1978 incorporó el aprovechamiento medio en suelo urbanizable y, en alguna medida, según se ha admitido por la doctrina, las transferencias de aprovechamiento urbanístico en el suelo urbano, al que se dirigió, como ya ocurriese en la LS1956, muy escasa atención. Con la frustrada reforma de 1990-1992, vulnerando la distribución constitucional de competencias, se regularon el aprovechamiento tipo y las áreas de reparto excluyendo únicamente el suelo no urbanizable, carente por definición de aprovechamiento urbanístico. Y pese a que la reforma de 1998 trató de devolver la situación a los planteamientos de la de 1975-1978, lo cierto es que las normas autonómicas han mantenido y potenciado técnicas equidistributivas diversas, inspiradas en general en las diversas propuestas de la normativa estatal. Esta evolución hacia una imposible equidistribución universal no es casual. Profundizar en las técnicas redistributivas se concibe en España como presupuesto de la recuperación de plusvalías por la comunidad y así lo ponen de manifiesto la evolución legislativa y la práctica urbanística. any funding. The resignation was explicit in the exposition of the motives in the LS1956 where it was admitted that even though it would be ideal that all the land required for population expansion, once urbanized, was of public property and offered through fair procurement to those willing to build the solution, in Spain this was not feasible. It would require extremely large funds, which cannot be diverted from other national objectives, without causing serious losses to property and private initiative. It is no surprise that after the reform of 1975-1978, the act itself admitted the private character of the urban capital gains, demanding anyhow a percentage for the Administration, set down in the form of urban tithe of the average utilization of the property. There was no other possible model than the equidistributive one.

The urban legislation first and the urban planning afterwards incorporated institutions and techniques whose main aim was to reduce the tensions generated by the assignation of the land uses, on one hand (14), and, on the other, to achieve an equitable distribution of benefits and burdens between owners (11). From all of it several concepts emerged, together with land subdividing: average utilization, standard utilization, benefits transferences, forced economic land subdividing in urban soil and compensations between both surplus and deficit scenes and other similar institutions. That land subdividing philosophy, that management anticipation, influenced the planning determinations and is the foundation of the current urban planning law. From those urban planning standards, that seek to promote economic activity, that revalue the land with the mere adoption of urban plans, and that assign most part of the management and the capital gains to the landowners because the ideal of urbanism was unachievable, emerged our cities and villages as in their current configuration.

The equitable sharing of benefits techniques and burdens were a result of the need of finding a funding entity capable for the implementation of the plans, that due to their content generated inequality between the affected owners. It was meant to correct what the doctrine called the planning lottery (10) (13), the prize that the owners of lands with lucrative benefits got with the mere approval of the plan. In order to correct it, the LS1956, in a legislative context in favor of the owners, regulated the land subdividing reformulating the concept of private property and social function. The reform of 1975-1978 incorporated the average utilization of urbanized soil and, to some extent, as it has been admitted by the doctrine, the urban utilization transferences in the urban land, to which little attention was given as it previously occurred with the LS1956. With the frustrated reform of 1990-1992, breaching the constitutional distribution of competences, the standard utilization and the areas of distribution were regulated, excluding only the undeveloped land, which lacks by definition of urban utilization. Even though the reform of 1998 tried to get the planning situation back to the approaches of 1975-1978, the truth is that the autonomic regulations have kept and promoted diverse equidistributive techniques, inspired in general on the various proposals of the national framework. This progression towards an impossible universal equidistribution is not casual. Investigating the redistributive techniques is conceived in Spain as a presupposition of the recovery of capital gains by the community, as can be inferred from the legislative evolution and urban planning practices. 
Pero la equidistribución como base de la actividad urbanística, como instrumento corrector de la desigualdad generada por el planeamiento, se basa en la idea de repercusión sobre el precio del producto inmobiliario final de todos los costes precisos para su producción. Y entre esos costes se han incluido no solo los de adquisición del suelo y urbanización, comprendiendo los fiscales y financieros, sino también otros, ya de base normativa como las cesiones de aprovechamiento y suelo, las reservas para usos concretos con precio limitado, ya convencionales como los pactados en convenio. Lógicamente, el modelo solo funcionará si tal repercusión resulta posible, es decir, si el precio resultante final permite asumir todos los costes, nunca en caso contrario. A ello hay que añadir el limitadísimo alcance que los fondos propios de la empresa inmobiliaria tenían en la práctica, de modo que todo el proceso se afrontaba con capitales ajenos, crédito promotor que al final se transformaba en crédito adquirente. Pasamos así de la idea de reparto para hacer posible la ejecución del plan a una percepción del urbanismo como un instrumento financiero. Y por tal camino llegamos, desbocado el crédito más allá de parámetros racionales y razonables, escalando los precios hasta el límite determinado por la capacidad de pago de los adquirentes en función de su renta, estancada, y del coste financiero, a la burbuja. No es extraño que algunos pretendiesen una especie de reparcelación universal en la que todo propietario pudiese participar, pretensión dura y fundadamente criticada (15). Esta sublimación de la lógica del modelo de 1956 lo llevaba al absurdo (16) (17) (18).

La normativa urbanística arraigada en el ensanche poco más proponía en suelo urbano que la traslación de técnicas concebidas para la expansión, como los planes especiales, la reparcelación en esa clase de suelo o las que denominó actuaciones aisladas, de base expropiatoria previo reconocimiento de la incorporación del aprovechamiento a la propiedad del suelo (10). A las dificultades para la efectiva gestión en suelo urbano se unían, además, las igualmente existentes para la protección de la edificación existente o de la propia ciudad, ya que la ruina hacía cesar el deber de conservación, habilitando así la sustitución de la edificación sin que la posible imposición de vinculaciones singulares en un entorno de ausencia de fondos públicos para articular las indemnizaciones pertinentes constituyese solución alguna. Lo que los años ochenta del siglo pasado pusieron de manifiesto es que solo cuando la plusvalía y el crédito no alimentan la expansión surge el apetito por la rehabilitación edificatoria y urbana. Hoy estamos en uno de esos momentos.

\section{LA EXPLOSIÓN DE LA BURBUJA Y EL FINAL DE UN MODELO}

Atendiendo a lo ya expuesto, el estallido de la burbuja inmobiliaria y los efectos que la sobrevaloración de activos inmobiliarios habían de producir en los balances de las entidades de crédito y en el conjunto de la economía eran perfectamente previsibles y fueron previstos, aunque negados por los más beneficiados por el modelo (19) (20). El mercado inmobiliario en España no se construyó sobre oferta y demanda, concebidas como arcanos económicos, sino sobre parámetros más perversos, los de precio y renta familiar disponible.

El sistema urbanizador y edificatorio español, ayuno de inversión pública y con escasos fondos propios en la empresa inmobiliaria, entró en quiebra al unirse la crisis financiera internacional, agravada por la dependencia exterior de nuestro sistema financiero (21) con unos precios inasumibles en términos de renta familiar disponible. Apenas en diez años un
But the equidistribution as basis of the urban activity, as a correcting instrument for the inequality generated by the urban planning, is based on the idea of passing on all the production costs to the prize of the final real state product. Among those costs were not only the economic ones derived from the acquisition of the land and its urbanization, but also the regulatory ones, such as the cessions of the land and its utilization or the reserves for specific uses with limited prize, as the collective agreements. Logically, the model only works if passing on the costs is possible, i.e. if the resulting final prize can assume all the costs, never otherwise. The limited reach of the real state funding must be added to all this, being all the process funded by outside capital, developers' credit that turned into the purchaser's credit. We so move from the idea of distribution in order to make possible the implementation of the plan to a perception of urbanism as an economic instrument. And in that context, once the credit surpasses all the rational and reasonable parameters and the prices rise up to the limit determined by the purchaser's capacity of payment depending of their incomes, we arrived to the bubble. It was not uncommon that some kind of universal land subdividing where every owner could participate was tried, severe intention on good grounds criticized (15). This sublimation of the 1956 model logics lead it to the absurd (16) (17) (18).

The urban planning regulation, deep-rooted in the ensanche, only proposed for urban soil the translation of the techniques conceived for expansion, such as the so called special plans, the subdivision in this kind of land or what was denominated isolated interventions, which were mainly of expropriation nature prior acknowledgment of the incorporation of the utilization to the land property (10). Besides the difficulties for the effective management of the urban land, other issues had to be faced such as the existing buildings protection and city preservation. This was due to the fact that the ruin status stopped the preservation duty and buildings replacement was thus allowed, not being a plausible solution the imposition of singular connections -in a public fund-less environment- to articulate the rightful compensations. The eighties underscored that only when capital gains and credit are not "feeding" the expansion, the concept of building and urban renewal catches the attention of society. Today, we are going through one of those moments.

\section{THE REAL-STATE BUBLE BURST AND THE END OF A MODEL}

In the light of the above, the real-state bubble burst and the effects that the overestimation of the real-estate assets could produce in the balance sheets of credit institutions and the economy were indeed predictable, even though the ones benefiting from the model denied it (19) (20). The real estate market in Spain was not built on the supply and demand, seen as economic arcane symbolisms, but on more perverse parameters, such as the price and the disposable household income.

The Spanish urbanizing and building system, lacking of public investment and with scarce own funds in the real-state scene, collapsed when joined the international financial crisis, aggravated due to the foreign dependence of our financial system (21) with unaffordable prices in terms of disposable household income. In barely ten years, 
incremento de los salarios del cuarenta por ciento soportó un incremento del precio de la vivienda del cuatrocientos por ciento, solo asumible por la reducción de los costes financieros, la sobreproducción de productos inmobiliarios, la inmigración y la incorporación de la mujer al mundo laboral, entre otros factores. Pero en ese contexto, se financiaron operaciones de crédito inmobiliario obviando o agravando riesgos evidentes, sin exigir el histórico compromiso de fondos propios, ignorando elementales principios de crédito responsable que la normativa reciente solo de manera muy imperfecta, y voluntaria para las entidades de crédito, ha tratado de garantizar. Y esta financiación se concedió para la adquisición de suelo, no finalista muy frecuentemente, la promoción o la adquisición de productos inmobiliarios. El crédito se titulizó y los títulos se colocaron en mercados financieros derivados para generar más liquidez con la que seguir financiando otras operaciones no menos arriesgadas, captando masivamente liquidez del exterior del país; los precios subieron y subieron tanto más cuanto más se abarataron los costes financieros y aumentaba la capacidad nominal de pago de las familias; la renta familiar disponible, sin embargo, era cada vez menor y la situación se agravó con un leve repunte de los tipos de interés, que hizo el riesgo ya inasumible, imposible de obviar. El crédito se retrajo bruscamente, frenando en seco al sector inmobiliario. Las entidades de crédito empezaron a desconfiar unas de otras y, lo que es más grave, de todas las españolas empezaron a desconfiar los mercados. En el momento álgido del ciclo, a mediados de 2008 , el crédito inmobiliario en sus modalidades de crédito constructor, promotor y a adquirentes igualaba el producto interior bruto del país.

La crisis alcanzó sucesivamente a gestores de suelo, urbanizadores, pequeños y medianos promotores y grandes grupos inmobiliarios. Como colofón se produjo un súbito incremento del desempleo, incrementándose así el gasto público notablemente. Aumentaron también, lógicamente, la mora y las ejecuciones hipotecarias (22). Se inició un proceso de concentración y reestructuración del negocio bancario en España, generando así entidades demasiado grandes para caer. Municipios, Comunidades Autónomas y Estado no estaban en mejor situación. Vieron rápidamente mermados sus ingresos, muy vinculados al sector inmobiliario, y, en el caso de los municipios y las Comunidades Autónomas constantes o al alza sus gastos, muy al alza por los costes sociales en el caso del Estado. Y los precios empezaron a bajar, rápida e inexorablemente. No había otra salida. Y la financiación exterior a los sectores públicos y crediticio español, dada la situación, desapareció. Los daños fueron tales que solo pudieron afrontarse mediante una masiva inyección de fondos públicos (obtenidos de la Unión Europea bajo rigurosas condiciones), acompañada del saneamiento de los balances de las entidades de crédito más afectadas, mediante dotaciones y segregación de los activos dañados obligatoriamente transferidos a la sociedad de gestión de activos procedentes de la reestructuración bancaria. No era difícil de prever. Si en relación con la burbuja anterior Naredo ya identificó en 1996 el masivo endeudamiento como su principal causa interna (23), otro autor, Fernández Durán, avisó en 2006 de un estallido a escala global de la burbuja inmobiliaria y financiera con graves repercusiones sobre la economía real (18).

Sin embargo, en España el conjunto de los poderes públicos y económicos, y el propio Tribunal Constitucional, que tuvo ocasión de pronunciarse no hace mucho, una vez más, sobre la cuestión hipotecaria (20), o el Tribunal Supremo, que recientemente ha otorgado primacía a los intereses del a rise of the $40 \%$ in salaries supported a rise of the $400 \%$ in housing prices, only affordable due to the reduction of the financial costs, the overproduction of real-state product, the immigration and the incorporation of women in the job market, among other factors. But in this context, credit realestate operations were financed, ignoring or aggravating evident risks, not requiring the historic commitment of own funds, ignoring responsible elementary credit principles that recent regulations -only in a very imperfect way and with voluntary character for the credit institutions- has tried to guarantee. And this funding was conceived for the land acquisition -frequently non finalist- and for the promotion and acquisition of real-state products. The credit was securitized, and the rights were out in the secondary financialmarkets to generate more liquidity that would allow keep funding other risky operations, attracting massively foreign liquidity. The cheaper the financial costs were and the higher the families' nominal capacity of payment, the higher the prices rose. The households' disposable income, however, kept lowering and lowering, and the situation was aggravated with a slight increase of the interest rates, making the risk -that was already unbearable-impossible to be ignored. The credit abruptly decreased, leading to a sudden halt of the real-state sector. The credit entities started distrusting not only one another but, even worse, the markets as well. At the peak of the cycle, in mid-2008, the real-state credit in the modalities of property construction, development and acquisition matched the gross domestic product of the country.

The crisis reached successively land managers, urbanizers, small and middle developers and large real-state groups. To round off this period, a sudden unemployment rise took place, raising notably the public expenditure and, logically, the arrearage and mortgage executions (22). A process of concentration and re-structuration of the banking business started in Spain, thus creating too large companies to collapse. Municipalities, Regions and State were not at better situation. Their gains, closely related to the realstate sector, quickly decreased, whereas expenditure kept equal or went up for Municipalities and Regions, and significantly grew up for the State due to social costs. And so the prices started to sink quick and inexorably. There was no exit. And all foreign funding for the Spanish public Administration and credit sectors, due to the situation, faded away. The harm was such that it could only be faced through a massive injection of public funding (gotten from the $E U$ under rigorous demands) and through the correction of the more deeply affected credit entities' bank balance sheets, by means of budgetary allocations and segregations of damaged assets, compulsorily transferred to the asset management company created by the banking restructuring. This situation was not difficult to be foreseen. If when referring to the previous bubble, Naredo already identified in 1996 as the main cause the massive indebtedness (23), another author, Fernández Durán, warned in 2006 of a global-scaled real-estate and financial bubble about to burst with serious economic repercussions for the real economy (18).

In Spain, however, the ensemble of public authorities and economic operators, the Constitutional Tribunal itself that had the opportunity to express its opinion, once more, on the mortgage matter- (20), or the Supreme Court - that recently has given primacy to the interests of the financial 
sistema financiero sobre los de los particulares afectados por las clausulas suelo (24), asumen acríticamente un sistema hipotecario en manos privadas cuyo funcionamiento, sin controles efectivos, pone periódicamente en peligro la viabilidad económica del país y derechos básicos de los ciudadanos. Conviene no olvidar, recordando viejos consensos, que el modelo hipotecario actual fue acordado por las fuerzas políticas de la transición en los Pactos de la Moncloa de 27 de octubre de 1977. Desde entonces no solo no se ha cuestionado en sede política sino que parece inmune a toda crítica. Solo en sede judicial se ha empezado a discutir, con endeble base legal.

Los excesos del sector inmobiliario español están en el origen de la actual situación del sistema financiero y de la necesidad de su saneamiento, que el Banco de España no pareció advertir (20). Nuestro sector inmobiliario, con la connivencia del financiero, se convirtió en un gigante con pies de barro confiado en mitos como que el precio de la vivienda nunca caería o que alquilar era tirar dinero. La crisis ha dado lugar a nuevas falacias, que de nuevo el tiempo está desvelando, como la afirmación de la actual reducción del esfuerzo para adquirir una vivienda, la desaparición del stock o el fin, varias veces anunciado, de las caídas de precios (25) (26) (27). La quimera inmobiliaria de la década prodigiosa del urbanismo español concretada en una inmensa burbuja inmobiliaria y elevados riesgos crediticios, negada por una mayoría de políticos, financieros, empresarios y economistas (27), dio paso al actual colapso financiero que ha asolado el país y que el Banco de España, tardíamente, apenas acertó a entrever (28).

La semilla del imprescindible proceso de saneamiento del sistema financiero español se plantó hace tiempo, al igual que la crisis que había de asolar un sector inmobiliario insostenible. Pero el derecho urbanístico y el modelo crediticio e hipotecario de la burbuja, aunque no las políticas de vivienda, continúan vigentes. Y ello pese a que en ausencia de plusvalía la equidistribución no sirve de nada. Por eso se están buscando alternativas que no dependan únicamente de la plusvalía y la captación de crédito. Es en este contexto en el que ha de ubicarse la L3R.

\section{LA BÚSQUEDA DE ALTERNATIVAS: REHABILITACIÓN, REGENERACIÓN, RENOVACIÓN. UN FUTURO INCIERTO}

\subsection{Un punto de partida complicado: Un modelo antiguo arraigado, otro por construir}

La crisis inmobiliaria ha proporcionado al país la oportunidad de incorporar sus políticas urbanas a las que vienen ya impulsando hace años otros países volviendo la mirada a la ciudad tradicional. En ella, a través de la rehabilitación, la regeneración, la renovación y la reinvención del espacio urbano, pueden encontrarse respuestas más adecuadas a las necesidades sociales y a la actividad económica. La actual situación puede permitir superar una legislación urbanística, antes estatal y hoy autonómica, configurada siempre en España como legislación de ensanche, que favorece el consumo de suelo para atender teóricas necesidades manifestadas en forma de demanda financiable sin considerar la posibilidad de satisfacerlas con el tejido urbano ya existente. $\mathrm{Al}$ abandono por el urbanismo de la ciudad interior, excepto acaso para operaciones de renovación urbana o puntuales rehabilitaciones, se suma una tradicional regulación de la rehabilitación, tanto arquitectónica system over the ones of those affected by the "floor clauses" - (24), uncritically assume a real-estate market on private hands, whose behavior, with no effective controls, systematically puts at risk the economic viability of the country and the basic rights of its citizens. Having old agreements in mind, it is convenient not to forget that the current mortgage model was set by the politic forces of the transition in the Moncloa Pacts of October 27, 1977. Since then, not only have they never been politically questioned, but they also seem to be immune to any critic. They are only now starting to be discussed in the courts and with a poor legal base.

The excesses of the Spanish real-state sector are the origin of the current situation of the financial system and of the need of sanitation that the Bank of Spain failed to notice (20). Our real-state sector, with the collusion of the financial system, turned out to be a giant with feet of clay, trusting in myths such as that dwelling prizes could never fall or that hiring was wasting your money. The crisis has originated new fallacies, that time is uncovering one more time, sucha as the current effort reduction to acquire a dwelling, the stock disappearance or the end, many times predicted, of the prices fall (25) (26) (27). The real-state chimera of the prodigious decade of the Spanish urbanism, consisting of an immense real-state bubble and high credit risk-denied by most of the politicians, financiers, businessmen and economists- (27) led to the current financial collapse that has devastated the country and that the Bank of Spain barely foresaw (28).

The seed of the essential sanitation process of the Spanish financial system was planted a long time ago, and so did the crisis, meant to devastate an unsustainable real-state sector. But the urban planning law and the credit and realstate model of the bubble still prevail (not the housing politic though). And this despite the fact that in the absence of capital gains, the equidistribution is worthless. That is the reason why alternatives non dependant exclusively on the capital gains and the credit intake are being sought. This is the context in which the $L_{3} R$ has to be inscribed.

\section{THE SEARCH FOR ALTERNATIVES: RENEWAL, REGENERATION, RENOVATION. AN UNCERTAIN FUTURE}

\subsection{A difficult starting point: one old deep-rooted model, another model to be built}

The real state crisis has given the country the opportunity to incorporate urban policies that other countries have already promoted for years, looking back to the traditional city. In this model, through renewal, regeneration, renovation an urban space re-invention, more adequate answers to social need and economic activity can be found. The current situation provides the opportunity to overcome this urban legal framework, which was previously state-related and now regional, configured in Spain as an ensanche legislation that promotes the land use in order to satisfy theoretical needs manifested as fundable demands that does not consider the possibility of satisfying them with the existing urban fabric. Besides the neglect of the inner city by urbanism, except for minor urban reconfiguration operations and occasional building refurbishment, the traditional regulation of the architectonic and integrated 
como integrada, orientada a lograr la regeneración de la ciudad existente, caracterizada históricamente en España por su fragmentación, su accesoriedad y, dada su vinculación parcial a los planes de vivienda, por su contingencia.

La rehabilitación edificatoria y urbana ha sido la gran ausente de la normativa urbanística, limitada a una escasa regulación de las actuaciones de reforma interior, dirigida fundamentalmente a la intervención sobre la trama urbana y que obvia, en general, la intervención sobre la edificación existente y el impacto que la misma puede tener sobre conceptos como aprovechamiento, espacios libres o urbanización. El triunfo del ensanche supuso el abandono de las técnicas operativas para la reforma interior y entre ellas, de forma destacada, la de expropiación. Pero esas lagunas no han impedido la imposición legal de auténticas obligaciones de rehabilitación, basadas en las determinaciones resultantes de los planes o sus catálogos o en la regulación, cada vez más amplia, del deber de conservación.

A la imprecisión de la normativa urbanística se une también su falta de conexión con la normativa sobre propiedad horizontal, siendo tal régimen jurídico el ordinariamente aplicable en la gran mayoría de intervenciones que se realicen sobre entornos urbanos. Tampoco la normativa fiscal favorecía este tipo de procesos, al orientarse hasta tiempos recientes la práctica totalidad del gasto fiscal en el ámbito de las políticas de vivienda a favorecer el acceso a la vivienda en propiedad y, a la postre, la promoción de vivienda de nueva construcción para venta 0 , tan solo ocasionalmente, el alquiler. Y tampoco ayudaba en exceso, como ya he explicado, la normativa técnica de edificación, centrado el CTE en la edificación de nueva planta. El corolario de esta situación eran unos planes de vivienda insuficientemente dotados, con objetivos excesivamente abiertos y contingentes en el tiempo, limitando su vigencia a cuatro años.

No resulta fácil pero sí posible concebir e implantar otro modelo cuyo eje no sea la vivienda en propiedad, o la promoción de vivienda de nueva construcción para venta, ni el parámetro determinante de los precios del suelo el endeudamiento máximo asumible por los ciudadanos o las empresas, un modelo que pondere la capacidad residencial de la ciudad existente, que analice los déficits de la edificación existente y de la propia ciudad y que programe las intervenciones sobre una y otra para dar otra respuesta a las necesidades de alojamiento y servicios reduciendo y optimizando el consumo de suelo y recursos naturales.

\subsection{El horizonte de trabajo: simplificar, afrontar nuevos riesgos, reequilibrar intereses en juego}

En la interrelación entre urbanismo, rehabilitación edificatoria y regeneración urbana está la respuesta a muchas de las incertidumbres que la quiebra del modelo tradicional en España está planteando hoy día. En especial, el equilibrio resultante de tales acciones puede resolver las tensiones entre crecimiento y regeneración condicionando las decisiones que determinen consumo de nuevos suelos al previo análisis de la capacidad real de los existentes, incluyendo en su caso los costes precisos para optimizarla.

Las bases teóricas de ese modelo están ya planteadas, pero sus bases legales resultan todavía muy endebles, aunque la LS y la L3R han supuesto un notable avance en esta línea. Y todavía más débil es su base financiera, una vez el sistema de fomento que se inició a principios de los años ochenta del siglo pasado, debido a refurbishment, aiming to regenerate the existing city, has historically been characterized in Spain by its fragmentation, its secondary nature, and, given its partial connection to housing planning, by its contingency.

Building and urban renewal has been the great missing piece in Spanish urban regulations, limited to a scarce regulation of the inner reform interventions, and mainly aiming to intervene in the urban fabric which, in general, ignores the interventions in existing buildings and the impact that it may have in concepts such as utilization, open spaces or urbanization. The success of the ensanche implied the abandonment of the operational techniques of the inner reform and, among them, prominently, the expropriation. But those gaps have not prevented the legal imposition of real renovation obligations, based on the resulting determinations of the plans or catalogues and the regulation of the duty of preservation, increasingly more comprehensive.

To the urban normative inaccuracies, it is added its lack of connection to the horizontal property regulations, which is the legal regime normally applied in most of the interventions carried out in urban contexts. On the top of this, the tax regulations did not facilitate this kind of processes, since until recently the almost entirely taxation expenditure in the housing politics context was aimed at facilitating the access to dwelling ownership and, in the longer term, at promoting new housing to be sold or occasionally to be rented. It did not help either, as previously stated, the fact that the Technical Building Code, was focused on the new build construction. The corollary of this situation was housing plans characterized by insufficient consistency, too open objectives and time contingency, limiting their validity to four years.

It is possible, but not easy, to design and implement another model whose main focus is neither dwelling ownership, nor the promotion of new build construction for sale. Nor would the parameter that sets the land price be the maximum debt that citizens or companies can afford. It should be a model that weighs the housing capacity of the existing city, that analyzes the existing buildings and the city needs, and that schedules the intervention on both in order to give another answer to housing and service needs reducing and optimizing the land use and the natural resources consumption.

\subsection{The working horizon: simplifying, taking new risks, rebalancing the interests at stake}

The interrelation between urbanism, building refurbishment and urban regeneration is the answer for many of the uncertainties arising nowadays with the collapse of the traditional Spanish model. The balance resulting from such actions may resolve the tensions between growth and regeneration, conditioning the decisions that determine new land uses to a previous analysis of the real capacity of the existing ones, including in that case the precise costs for its optimization.

The theoretical bases of such model are already set, but their legal bases are still weak, even though the $L S$ and the $L_{3} R$ represent a significant progress in this area. Yet weaker is the financial basis, once the promoting system started in the early eighties has proved to become definitely unsustainable 
la contingencia, sus deficiencias y su evidente insuficiencia aun en los momentos en que fue mejor dotado presupuestariamente, parece haber devenido definitivamente insostenible.

En el marco de una notable simplificación normativa, que superase la percepción del derecho urbanístico como regulación de la propiedad del suelo, postergando otros derechos, libertades e intereses privados y públicos, es precisa la clarificación conceptual y finalista de rehabilitación edificatoria y urbana, dando respuesta al problema de los vacíos urbanos, de los suelos clasificados transformados y no ocupados o de los simplemente clasificados y cuya urbanización no resulta previsible en un horizonte razonable. Son necesarios un ordenamiento urbanístico y unas políticas de vivienda y rehabilitación renovados que superen el desarrollismo concebido como motor económico, el modelo hipotecario piramidal en el que las entidades de crédito ostentan privilegios exorbitantes sin garantías reales de una adecuada valoración de la capacidad de pago de los prestatarios, y el sistema de satisfacción del derecho a la vivienda basado en la propiedad.

La intervención sobre la edificación y la ciudad existente genera nuevos riesgos, lógicamente, que han sido detectados por las actuaciones desarrolladas hasta el momento y pueden ser afrontados con un tratamiento interdisciplinar adecuado que implique, junto arquitectos, urbanistas y juristas, a otros colectivos profesionales como los geógrafos, los sociólogos o los trabajadores sociales. La obsolescencia de parte de nuestro parque edificado y del tejido urbano y las redes de equipamientos y servicios que lo sustentan no es solo urbanística o constructiva, es también energética y social. De ahí que el derecho y la práctica rehabilitadora deban ser necesariamente integrados. No puede tener lugar a costa de la población actual que, además, habitualmente es de edad avanzada y/o de bajo poder adquisitivo cuando no perteneciente a colectivos excluidos o en riesgo de exclusión social.

Y tampoco resulta admisible a costa de la saturación de los servicios y redes existentes al no redimensionarse para atender a la nueva población. La búsqueda de la viabilidad financiera de las actuaciones, sin duda imprescindible como ha explicado hasta la saciedad el GTR (29) (30) (31), no debiera lograrse a costa de reproducir errores del pasado que todo lo fiaban a la actuación sobre los aprovechamientos olvidando la necesidad de intervenir integralmente sobre el entorno urbano de que se trate. El planeamiento urbanístico debe integrar como objetivo fundamental la rehabilitación arquitectónica y urbana analizando de forma exhaustiva el parque edificado, las dinámicas de ocupación y los flujos de población identificando usos anómalos, estudiando la posible segmentación social o generacional de la ciudad y, en función de todo ello, concretadas las áreas vulnerables y las necesidades, justificar el consumo de nuevo suelo por la urbanización.

Igualmente insatisfactorio resulta el modelo regulatorio de deber de conservación y ruina vigente en España, especialmente dada su conexión con la normativa reguladora de los arrendamientos urbanos, que convertía el incumplimiento del deber de conservación, ante la inacción o impotencia administrativa, en el camino para que el propietario pudiera liberarse de inquilinos (32) (33) (34). Parece razonable también corregir y prevenir en el futuro la existencia de parque de vivienda vacía, reforzando la exigencia de motivación al planeamiento, estableciendo estímulos y generando un tejido empresarial o cooperativo que garantice una gestión adecuada y sostenible en el tiempo (35). due to its contingency, deficiencies and evident insufficiency even during the periods when it had higher budgetary provisions.

In a framework with a notably simplified regulation, that overcomes the urban planning law perception as just a landownership regulation, and putting off other rights, liberties and public and private interests, it is necessary a conceptual clarification and a definition objectives of building and urban renewal, addressing the urban voids problematic, the non-occupied classified lands with transformed uses or the classified lands whose urbanization is not foreseeable in a reasonable time horizon. Renewed urban planning and housing renovation politics are necessary to overcome the developmentalism conceived as an economic engine, the pyramidal mortgage model in which the credit entities have exorbitant privileges with no real guarantees of a proper valuation of the borrowers' payment capacity, and the housing rights system based on housing ownership.

Logically, the intervention on buildings and the existing city generates new risks, that have been detected by the interventions carried out until the present moment, and that may be faced with a proper interdisciplinary treatment that would get involved architects, town planners and jurists, as well as geographers, sociologists and social workers. The obsolescence of part of our urban fabric and the equipment and infrastructure network behind it is not only urban and constructive, but energy-related and social as well. That is why the legal framework and the renovation interventions must necessarily be integrated. They cannot be done at the expense of the current citizens among whom the majority is formed by old people and/or with low purchasing power, or even pertaining to excluded groups or at risk of social exclusion.

It is also unacceptable at the expense of the saturation of services and existing networks due to lack of response to the new population. The search for the economic feasibility of the interventions -undoubtedly essential as the GTR has pointed out over and over (29) (30) (31)-, should not be achieved at the expense of repeating past mistakes, when everything relied on the use, forgetting the need for an integral intervention in the considered urban context. Urban planning must thus integrate - as its main focus- the architectonic and urban renewal, analyzing thoroughly the building stock, the occupation dynamics and the population fluxes and identifying abnormal uses, studying the possible social and generational segmentation of the city. Depending on these factors, and once the vulnerable areas and the needs have been identified, the use of new land for urbanization may be justified.

It is equally unsatisfying the current Spanish regulation model for preservation duty and ruin, specifically due to its connection with the regulatory legislation on urban leases, which made the non-compliance of the preservation duty the way for the owners to getting rid of tenants, against the inaction or administrative impotence (32) (33) (34). It seems also reasonable to correct and prevent the existence of urban voids in the future, reinforcing the demand of motivation in urban planning, providing incentives and generating a cooperative or business fabric able to guarantee a proper and sustainable management (35). 


\section{5•3. La propuesta de la L3R: La equidistribución, de nuevo}

La L3R ha tenido que ser, necesariamente, una norma compleja, tendente a sistematizar, por un lado, y a rectificar, por otro, las normas precedentes, muy fragmentarias, algo desordenadas y, probablemente por ello, contradictorias. En ella se afronta la regulación de la rehabilitación, la regeneración y la renovación urbanas, por supuesto, retocando las técnicas creadas ya en normas anteriores, pero también la reforma de la legislación estatal de suelo, del deber de conservación, de la inspección técnica de edificios (que sustituye por el informe de evaluación de los edificios), de la normativa de propiedad horizontal, de la normativa de edificación o de aspectos concretos de la hipotecaria, entre otras. Interesa centrar la atención, a los efectos de este trabajo, en dos cuestiones: las lagunas de la nueva norma desde la perspectiva fiscal y financiera y la apelación, ya tradicional en España cuando de urbanismo se trata, a la equidistribución de beneficios y cargas entre los afectados por las obligaciones derivadas de la nueva norma.

Sin duda el gran debe de la nueva norma estatal, como en la inmensa mayoría de normas urbanísticas españolas, radica en su vertiente financiera y fiscal. La L3R deja abierto el fundamental interrogante: ¿quién y cómo se financia la rehabilitación, regeneración y renovación urbanas? Ni lo resuelve la propia norma ni podrá buscarse la solución en las ayudas públicas. La respuesta que el legislador estatal da, como ocurrió en 1956, es el reparto de beneficios y cargas entre las personas afectadas por las actuaciones de rehabilitación y regeneración urbana, la equidistribución. En relación con ello se han suscitado las mayores críticas y ahí radica la mayor incertidumbre. La estrecha vinculación entre equidistribución y plusvalía hace que la viabilidad de los procesos de rehabilitación, regeneración y renovación urbana, salvo que consiga diseñarse un modelo de financiación que no dependa de la generación de plusvalías, quedará subordinada a la misma. Además, aun cuando la traslación del modelo de la expansión a estas actuaciones determina, como expondré, la afección real de las fincas que conforman el inmueble o inmuebles sobre los que se actúa al pago de las cargas resultantes de la actuación, la realidad pondrá de manifiesto las graves dificultades para ejecutarlos en caso de impago, especialmente cuando se trate de viviendas habituales. La combinación del régimen de propiedad horizontal, aun en su versión más flexible posterior a la reforma, con las garantías constitucionales y legales, crecientes, en torno a la vivienda, continuarán siendo obstáculos difíciles de salvar.

No es posible aquí desgranar de manera detallada todas las novedades, y problemas, que suscita la L3R. Pero sí resulta viable, y necesario, destacar los elementos fundamentales que estructuran la reforma. La L3R se fundamenta en la nueva regulación del deber de conservación y rehabilitación, lo que justifica la sustancial modificación de la LS en esta materia, en relación con las actuaciones sobre el medio urbano. Para impulsarlas limita la iniciativa a la Administración y a los propietarios (art. 9 L3R), otorgando un relevante papel a las comunidades de propietarios (art. 15.3 L3R) y dando entrada a personas o entidades no propietarias de acuerdo con los anteriores [art. 15.1, sobre su participación, y 10.2.a), 11.c) y $13.3 \mathrm{~L} 3 \mathrm{R}$ ]. Se potencia la potestad administrativa para dictar órdenes de ejecución siempre que, lógicamente, se encuentre delimitado el ámbito de la actuación de mejora urba-

\subsection{The L3R proposal: The equidistribution, one more time}

The $L_{3} R$ must have been a complex regulation, aiming to systematize, on one hand, and rectify, on the other, the previous regulations, which were highly fragmented, somewhat disordered, and probably because of this, contradictory. This law deals with the regulation of urban renewal, regeneration and renovation, adjusting of course the set of techniques already created by previous laws. It also addresses the reform of the national land law, the preservation duty legislation, the technical inspection of buildings (that it is replaced by the buildings evaluation report), the horizontal property regulations, the CTE or specific aspects of the mortgage regulation, among others. Two aspects of this adjustment must be highlighted in this paper: the tax and legal gaps in this new regulation, and the appeal to the concept of equidistribution of benefits and burdens among the affected for the obligations derived from the new regulation (already traditional in Spain when it comes to urbanism).

This new national regulation main must, as for the immense majority of Spanish urban regulation, lies on its financial and tax aspects. The $L_{3} R$ regulation leaves open the key question: who and how are urban renewal, regeneration and renovation be funded? The regulation itself is not able to give an answer, and the solution cannot be based on public funding. The answer given by the state legislator, as happened in 1956, is the distribution of benefits and burdens among the people affected by the urban renewal and regeneration interventions, i.e., the equidistribution. In this regard, criticism has aroused and it is therein where the main uncertainty lies. The close relationship between equidistribution and capital gains makes that the feasibility of the urban renewal, regeneration and renovation processes is subordinated to the latter, unless a financial model nondependent on the generation of capital gains is designed. On the top of this, even if the translation of the expansion model into these interventions determines (as will be stated) the real distribution of the burdens resulting from the intervention among the properties comprising the building(s) addressed, the reality will highlight the serious financial difficulties for implementing them in the event of non-payment, especially when it comes to dwellings. The combination of the horizontal property regulations, even in its more flexible version after the reform, with the growing legal and constitutional guarantees regarding housing, will remain constituting obstacles hard to overcome.

It is not possible to list in detail all the innovations and problems resulted from the $L 3 R$ here. But it is possible and necessary to highlight the fundamental elements that structure the reform. The $L_{3} R$ is based on the new regulation for preservation and renewal duties, what justifies the substantial modification of the LS in this matter concerning the intervention in the urban fabric. In order to promote them, it limits the initiative to the Administration and the owners (art. 9 L3R), giving an important role to the owners' communities (art. 15.3 L3R) who have the choice to allow the participation of external people and entities [art. 15.1, about the participation, and 10.2.a), 11.c) and 13.3 L3R]. It is promoted as well the administrative authority regarding the issuing of execution warrants provided that the field of intervention of the urban upgrades is defined (arts. 9.2 
na a la que se refieran (arts. 9.2 y 10.3 L3R). Establece también instrumentos de programación de estas actuaciones de mejora urbana, en el marco del planeamiento o al margen del mismo (art. 10.1 L3R), concretando sus efectos de modo similar a lo previsto para los planes (art. 12 L3R) y anticipando la gestión mediante equidistribución de las actuaciones (art. 10.2 L3R). La L3R regula igualmente la denominada memoria acreditativa de la viabilidad económica de las actuaciones de mejora urbana, en términos de rentabilidad, de adecuación a los límites del deber legal de conservación y de un adecuado equilibrio entre los beneficios y las cargas derivados de la misma para los propietarios incluidos en su ámbito de actuación (art. 11 L3R, que desarrolla su contenido mínimo).

La gestión de las actuaciones podrá tener lugar a través de todas las modalidades de gestión directa o indirecta admitidas por la legislación de régimen jurídico, de contratación del sector público, de régimen local y de ordenación territorial y urbanística (art. 13 L3R), introduciendo así la máxima flexibilidad, al igual que ocurre con la generosa regulación de los convenios en este ámbito (arts. 13.3 y 17 a 19 L3R), previsiones lógicas dada la complejidad de las actuaciones de mejora urbana. Al margen de los acuerdos con terceros que pudieran alcanzar los propietarios cuando ellos impulsen y gestionen la actuación, la norma prevé expresamente la posible participación de terceros no propietarios en la gestión, mediando concurso, en los supuestos de gestión directa y de ejecución subsidiaria por la Administración (art. 13.2 y 3 L3R). Esta regulación ha generado también críticas por el riesgo evidente de que el empoderamiento de terceros en actuaciones de rehabilitación, regeneración o renovación en entornos sociales y económicos complejos, con población envejecida, acabe generando situaciones de acoso inmobiliario y gentrificación. La posición de la administración actuante para equilibrar la posición de todos los agentes resultará, sin duda, esencial desde esta perspectiva.

Pero, como he precisado anteriormente, dejando al margen otras previsiones que tratan de flexibilizar ocupaciones del dominio público o elementos comunes o privativos de los edificios en régimen de propiedad horizontal, por ejemplo, el quicio del sistema que impulsa la L3 R es a mi juicio, de nuevo, la equidistribución. En ausencia de recursos públicos para fomentar estas actuaciones y cuando están por construir y concretar otros mecanismos de financiación basados en los retornos o en los ahorros que pudieran producir las actuaciones de mejora urbana para sus beneficiarios, cuando no está clara en absoluto la voluntad del sector financiero de colaborar en el impulso de la rehabilitación urbana y de edificios, solo los propietarios y los restantes sujetos a los que obliga el deber de conservación tal y como ha quedado configurado en la L3R y la LS pueden asumir el coste, directa o indirectamente, de esas actuaciones.

Regulado el deber de conservar o rehabilitar (de modo análogo al deber de urbanizar en la expansión), una vez delimitada o autorizada por la Administración la actuación se produce «la afección real directa e inmediata, por determinación legal, de las fincas constitutivas de elementos privativos de regímenes de propiedad horizontal o de complejo inmobiliario privado, cualquiera que sea su propietario, al cumplimiento del deber de costear las obras» (art. 12.2 L3R). El acuerdo de delimitación o de autorización de las actuaciones incluirá «avance de la equidistribución que sea precisa, entendiendo por tal la distribución, entre todos los afectados, de los costes derivados de la ejecución de la correspondiente actuación y de los beneficios imputables a and $10.3 \mathrm{~L} 3 \mathrm{R}$ ). Instruments for the programming of these interventions of urban upgrade are also established either within or outside the urban planning framework (art. 10.1 $L_{3} R$ ), specifying their effects in a similar way to what was envisioned for the plans (art. $12 L_{3} R$ ) and anticipating the management through the equidistribution of the intervention (art. 10.2 L3R). The $L_{3} R$ regulates as well the so-called certifying report of the economic feasibility of the urban upgrade interventions, in terms of profitability, in terms of adequacy to the limits of the legal preservation duties and in terms of an adequate balance between benefits and burdens for the owners included in the intervention area (art. $11 L_{3} R$, addressing the minimum contents).

The intervention management may take place through any of the direct or indirect management modalities approved by the legal system legislation, on public sector procurement, local regime, and regional and urban planning (art. 13 L3R), introducing this way the maximum flexibility, as in the generous regulation of conventions in this area (arts. 13.3 and 17 to $19 \mathrm{~L}_{3} R$ ). These appear to be logical measures given the complexity of the urban upgrade interventions. Outside the agreements with third parties that the owners could reach when promoting or managing the intervention, the regulation expressly foresees the possible participation of non-owner third parties in the management, through public contest, in case of direct management and subsidiary execution by the Administration (art. 13.2 and 3 L3R). This regulation has also generated criticism due to the evident risk that the empowerment of the third parties in the interventions of renewal, regeneration or renovation in social and economically complex environments, with old population, may eventually generate situations of real estate mobbing and gentrification. The role of the urban authorities in order to balance the position of every agent involved will result being essential from this perspective.

But, as previously stated, leaving aside other measures that try to make more flexible occupations of public domain or of common or restrictive use elements of the buildings in horizontal property regime, what in my opinion is the basis of the system promoted by the L3R, is, again, the equidistribution. In absence of public funding for promoting these interventions, and when other funding mechanisms -based on the returns or the savings that urban upgrade interventions may produce to their beneficiaries-are yet to be designed and generated, when it is not clear at all the willingness of the economic sector to collaborate in the promotion of urban and building renovation, only the owners and remaining parties that must comply with the preservation duty as stated in the $L_{3} R$ and the LS can assume the cost of these interventions, either direct or indirectly.

Regulated the duty of preservation and renovation (in an analogous way to the urbanization duty in the expansion), and once the intervention is authorized and delimited by the Administration, the owners of the legally determined constituent buildings of elements of restrictive use belonging to horizontal property systems or private property complex, have the duty of financing the works (art. 12.2 L3R). The delimitation agreement or the authorization of the interventions will include the necessary equidistribution advances, such as the distribution among all concerned of the costs of executing the corresponding action and the profits attributable to it, including among the latter state aids and 
la misma, incluyendo entre ellos las ayudas públicas y todos los que permitan generar algún tipo de ingreso vinculado a la operación» [art. 11.2.a) L3R]. La rentabilidad de la actuación, determinante de su viabilidad, es objeto, como ya he señalado, de la indispensable memoria de viabilidad económica (art. 11 L3R).

La administración, cuando gestione directamente la actuación o asuma su ejecución subsidiaria en caso de incumplimiento, supuesto este en el que sustituye al titular o titulares del inmueble asumiendo la facultad de edificar o rehabilitar con cargo a los mismos, podrá adjudicar la gestión «por medio de la convocatoria de un concurso público, en cuyo caso, las bases determinarán los criterios aplicables para su adjudicación y el porcentaje mínimo de techo edificado que se atribuirá a los propietarios del inmueble objeto de la sustitución forzosa, en régimen de propiedad horizontal» (art. 13.3 L3R). Entre los criterios que han de establecerse para la adjudicación se prevén como preferentes, por un lado, la oferta de condiciones más ventajosas para los propietarios afectados (salvo en los casos de incumplimiento de la función social de la propiedad o de los plazos de ejecución establecidos), previendo incentivos, atrayendo inversión y ofreciendo garantías o posibilidades de colaboración con los mismos; y por otro, las ofertas que produzcan un mayor beneficio para la colectividad en su conjunto y propongan obras de eliminación de las situaciones de infravivienda, de cumplimiento del deber legal de conservación, de garantía de la accesibilidad universal o de mejora de la eficiencia energética (art. 13.3 L3R).

Resultará esencial, en estos supuestos especialmente, la distribución equitativa de beneficios y cargas. $\mathrm{Y}$ ello porque se impondrá un reparto entre el gestor y los propietarios, y no solo entre éstos, que no siempre será fácil o factible cuando el edificio lo integren viviendas destinadas a domicilio habitual y permanente. Ni siquiera las relevantes excepciones a la normativa expropiatoria de la L3R para estos casos (justiprecio en especie sin consentimiento del propietario y liberación de la expropiación no excepcional), permitirán resolver los problemas. La afección real de los elementos privativos de los inmuebles en régimen de propiedad horizontal al pago de las cargas difícilmente resultará efectiva cuando tales elementos privativos se destinen a domicilio habitual y permanente. Los propietarios, por lo demás, no tienen ninguna preferencia para la adjudicación de la gestión de la actuación, a la que podrán optar como cualquier otra persona física o jurídica interesada, si bien deberán constituir previamente una asociación administrativa (art. 13.3 L3R).

La L3R proporciona sin duda algunos nuevos instrumentos normativos para hacer factibles actuaciones de rehabilitación edificatoria y urbana. Pero la realidad económica del país la hace tributaria de una tradición equidistributiva que, al tiempo que constituye su esencial fundamento financiero, comporta su mayor debilidad. La equidistribución como técnica operativa solo funcionará si existe plusvalía. Lo demuestra la actual situación del sector inmobiliario. Es preciso profundizar en el nuevo paradigma normativo que trata de impulsar la nueva norma para conseguir que el país avance por el camino de la rehabilitación, regeneración y renovación urbanas. Pero ese nuevo marco normativo, todavía insuficiente, no bastará por lograrlo.

\section{AGRADECIMIENTOS}

Este trabajo se ha hecho en el marco del proyecto de investigación «Protocolo de Diseño Integrado para la Rehabilitación all those capable of generating some income related to the operation [art. 11.2.a) L3R]. The level of profitability, which determines its feasibility, is subject, as previously stated, to the required certifying report of the economic feasibility (art. $11 L_{3} R$ ).

When the Administration directly manages the act or assumes its subsidiary execution in the event of infringement, replacing the owner(s) and assuming the capacity to build or renovate at the owners' expense, it may allocate its management following a public tender, whose terms will determine the criteria for the allocation and the minimum percentage of built roof to assign to the property owners subject to forced substitution, in horizontal property regime (art. 13.3 L3R). Among the criteria to be established for allocation, the following are considered preferential: on one hand, the offer of more favorable conditions for the affected owners (unless in case of infringement of either the social function of the property or the established implementation deadlines), providing incentives, attracting investments and offering guarantees or collaboration possibilities; and on the other hand, the offers with a higher benefit for society as a whole and that propose the elimination of situations of substandard housing, the compliance of the legal duty of preservation, the universal accessibility guarantee or the improvement of the energy efficiency (art. 13.3 L3R).

It will be essential, especially in these cases, the equitable distribution of benefits and burdens. The reason is that a distribution between the manager and the owners, and other possible agents, will be necessary being this not always easy or feasible with the building is composed by dwellings with regular and permanent address. Not even the relevant exceptions to the expropriation regulations of the $L_{3} R$ for these cases (fair price in kind without the owner's consent and non-exceptional liberation of the expropriation) would solve these problems. The definition of elements of restrictive use of the buildings in horizontal property regime affected by the burdens will be hardly effective when such privative elements are used as regular and permanent dwellings. The owners have no preference regarding the allocation of the intervention management, being as eligible as any other physical or legal entity interested, even though they must have previously constituted as an administrative institution (art. 13.3 L3R).

The $L_{3} R$ undoubtedly provides some new regulatory instruments to make possible building and urban renewal interventions. But the economic reality of the country renders it dependent on a equidistribution tradition that, while constituting its essential economic basis, it also represents its main weakness. The equidistribution as an operative technique will only work if there is capital gain. The current real-state sector situation proves this assertion. There is a need for further investigation on the new regulatory paradigm that aims to encourage the country along the road to urban renewal, regeneration and renovation. But this new legal framework, still insufficient, will not be enough to achieve it.

\section{ACKNOWLEDGEMENTS}

This work has been carried out in the context of the research project "Integrated design protocol for social housing retrofit 
de la Vivienda Social y Regeneración Urbana» (BIA201344001-R) dentro del Programa Estatal de I+D+i orientada a los restos de la sociedad, financiado por el Ministerio de Economía y Competitividad. and urban regeneration" (BIA2013-44001-R) within the Spanish Research, Development and Innovation Program "Society's Challenges", funded by the Ministry of Economy and Competitiveness.

\section{REFERENCIAS / REFERENCES}

(1) Tejedor, J. C. (2010). Reflexiones sobre el estado de lo urbanístico. Entre la anomalía y la excepción. Revista de Administración Pública, 181: 83-133.

(2) Schulz-Dornburg, J. (2013). Ruinas modernas. Una topografía de lucro. Barcelona: Editorial Àmbit Servicios Editoriales.

(3) Tejedor, J. C. (Editor). (2013). Rehabilitación y regeneración urbana en España. Situación actual y perspectivas. Monografías de la Revista aragonesa de Administración Pública, XV: 1-319.

(4) La Ley de rehabilitación, renovación y regeneración. (2013). Número monográfico de Revista de derecho urbanístico y medio ambiente, 47(285): 1-219.

(5) Menéndez, A. (Coordinador). (2014). Por la rehabilitación, la regeneración y la renovación urbanas. Número monográfico de Ciudad y Territorio. Estudios territoriales, 179: 1-206.

(6) Rubio de Val, J. (Coordinador). (1990). La política de rehabilitación urbana en España. Evolución, experiencias y efectos. Madrid: Instituto del Territorio y Urbanismo.

(7) Bassols, M. (1973). Génesis y evolución del Derecho urbanístico español, p. 257, 331-397, Madrid: Montecorvo.

(8) Bassols, M. (1996). Los inicios del derecho urbanístico en el período del liberalismo moderado y en el sexenio revolucionario (1846-1876): el Ensanche de la ciudad como modelo urbanístico y sistema jurídico. Número monográfico sobre Siglo y medio de urbanismo en España, Ciudad y Territorio. Estudios territoriales, 1996(107-108): 19-51.

(9) Bassols, M. (1996). El derecho urbanístico de la Restauración a la II República (1876-1936): crisis de los Ensanches y las dificultades para alumbrar un nuevo modelo jurídico-urbanístico. Número monográfico sobre Siglo y medio de urbanismo en España, Ciudad y Territorio. Estudios territoriales, 1996(107-108): 53-90.

(10) García de Enterría, E., Parejo, L. (1981). Lecciones de Derecho urbanístico, p. 74-81, 94, 97, 494, Madrid: Civitas.

(11) Tejedor, J. C. (1998). Propiedad, equidistribución y urbanismo. Hacia un nuevo modelo urbanístico, p. 42-50, 27, 339365, Pamplona: Aranzadi.

(12) Lora-Tamayo, M. (2002). Urbanismo de obra pública y derecho a urbanizar, p. 309-313, 320-349, Madrid: Marcial Pons.

(13) García de Enterría, E. (1958). La Ley del Suelo y el futuro del urbanismo. Anuario de Derecho Civil, 11(2): 485-510.

(14) Fernández, T. R. (1973). El urbanismo concertado y la Ley del Suelo, p. 49, Madrid: IEA.

(15) García Bellido, J. (2005). Por una liberalización del paradigma urbanístico español (III): el tsunami urbanístico que arrasará el territorio. Ciudad y Territorio. Estudios territoriales, 2005(144): 273-288.

(16) García Bellido, J. (2004) Por una liberalización del paradigma urbanístico español. Ciudad y Territorio. Estudios Territoriales, 2004(140): 289-294.

(17) García Bellido, J. (2005) Por una liberalización del paradigma urbanístico español (II): la jurisprudencia de obras públicas en el límite del paroxismo. Ciudad y Territorio. Estudios Territoriales, 2005(143): 5-15.

(18) Fernández, R. (2006). El tsunami urbanizador español y mundial. Sobre sus causas y repercusiones devastadoras, y la necesidad de prepararse para el previsible estallido de la burbuja inmobiliaria, p. 63-65, Barcelona: Virus editorial.

(19) García Montalvo, J. (2008). De la quimera inmobiliaria al colapso financiero. Crónica de un desenlace anunciado, p. 209-223, Barcelona: Bosch.

(20) Tejedor, J. C. (2012). Derecho a la vivienda y burbuja inmobiliaria. De la propiedad al alquiler y la rehabilitación, p. 156-160, 150-154, Madrid: La Ley.

(21) Vega, J. M. (2011). La regulación bancaria, p. 261-314, Madrid: La Ley.

(22) Etxezarreta, A., Hoekstra, J., Dol, K., Cano, G. (2012). De la burbuja inmobiliaria a las ejecuciones hipotecarias. Ciudad y Territorio. Estudios Territoriales, 2012(174): 597-614.

(23) Naredo, J. M. (1996). La burbuja inmobiliario-financiera en la coyuntura económica reciente (1985-1995), Madrid: Siglo veintiuno de España editores.

(24) Alonso, M. T. (2014). Cláusulas frecuentes en préstamos hipotecarios para adquisición de vivienda: cláusula suelo, cláusula de vencimiento anticipado y cláusula de intereses moratorios. En Alonso, M. T. (Dir.), Vivienda y crisis económica. Estudio de las medidas propuestas para solucionar los problemas de vivienda provocados por la crisis económica (pp. 163-172). Pamplona: Gobierno de Aragón y Cátedra Zaragoza Vivienda, Aranzadi.

(25) García, J. (2007). Algunas consideraciones sobre el problema de la vivienda en España, Papeles de economía española, 2007(113): 138-153.

(26) García Montalvo, J. (19 de junio de 2011). Falacias inmobiliarias 2.o. El País. http://elpais.com/diario/2011/o6/19/ negocio/1308487946_850215.html.

(27) Burón, J. (2008). Una política de vivienda alternativa, Ciudad y Territorio. Estudios Territoriales, 2008(155): 12-14.

(28) Banco de España (2011). Informe anual 2010, p. 175, Madrid: Banco de España.

(29) Cuchí, A., Sweatman, P. (2011). Una visión-país para el sector de la edificación en España. Hoja de ruta para un nuevo sector de la vivienda, p. 32-34, Madrid: GBCe y Fundación CONAMA. 
(30) Cuchí, A., Sweatman, P. (2012). Informe GTR 2012. Una visión-país para el sector de la edificación en España. Hoja de ruta para un nuevo sector de la vivienda, pp. 75-83. Madrid: GBCe y Fundación CONAMA.

(31) Cuchí, A., Sweatman, P. (2013). Informe GTR 2014. Estrategia para la rehabilitación. Claves para transformar el sector de la edificación en España, pp. 49-60, 38. Madrid: GBCe y Fundación CONAMA.

(32) Tejedor, J. C. (1999). Deber de conservación, ruina y rehabilitación al servicio de la regeneración de la ciudad. Revista aragonesa de Administración Pública, 1999(14): 203-254.

(33) García Álvarez, G. (2013). Deber de conservación, ruina y rehabilitación. En Tejedor Bielsa, J. (Ed.), Rehabilitación y regeneración urbana en España. Situación actual y perspectivas. Monografías de la Revista aragonesa de Administración Pública, XV: 73-108.

(34) Iglesias, F. (2014). La regulación estatal del deber de conservación de inmuebles. En Menéndez, A. (Coord.), Por la rehabilitación, la regeneración y la renovación urbanas, Número monográfico de Ciudad y Territorio. Estudios territoriales, 2014(179): 51-62.

(35) Tejedor, J. C. (2013). Nuevos instrumentos de planificación y gestión de la rehabilitación arquitectónica y la regeneración urbana. En Tejedor Bielsa, J. (Ed.), Rehabilitación y regeneración urbana en España. Situación actual y perspectivas. Monografías de la Revista aragonesa de Administración Pública, XV: 27-72. 